resolution passed at the Quarterly Business meeting of the Royal College of Psychiatrists, 20 November 1981, had been proposed by Dr P. Sainsbury and seconded by Dr G. Low Beer.

“... this General Assembly resolves that the withdrawal of the membership of the All-Union Society of Neurologists and Psychiatrists of the World Psychiatric Association should now take place until such time as... to an end."

Professor Rawnsley announced that the World Psychiatric Association had informed the Royal College of Psychiatrists that the All-Union Society of Psychiatrists of the USSR had resigned from membership of the World
Psychiatric Association. The All-Union Society had written to all member societies of the World Psychiatric Association and the College was awaiting this letter. Since the resolution in 1981, the College had received communications and a visit from the Russian Embassy as well as an unconfirmed invitation to take part in a multi-national delegation to visit the USSR.

Dr P. Sainsbury and Dr G. Low Beer expressed their regret at the decision of the Russian psychiatrists. It was hoped that in a few years the situation might ameloriate and channels of communication would be re-opened. In the meantime the Special (Political Abuse of Psychiatry) Committee should endeavour to envisage ways in which pressure could be maintained on the Soviet Union.

\title{
Reports from the Divisions
}

\section{Welsh Division}

The Welsh Division held two meetings in the course of 1982. The Spring Meeting was held at Cefn Coed Hospital, Swansea, on 3 April.

The morning programme was provided by members of the consultant staff of Cefn Coed Hospital. Dr T. G. Davies spoke on 'Bedlam in Wales'-a history of the evolution of Psychiatric Services in South Wales in the 19th century. Dr Gareth Hughes, in 'The Self-Poisoners of Aqua Sulis', presented a study of overdosage in the City of Bath, relating the incidence of self-poisoning to a variety of social parameters.

In the afternoon papers were presented by members of the Postgraduate Section and the Section of Mental Subnormality. In the first Dr Marshall Annear (Morgannwg Hospital) reviewed the development of Postgraduate Education in Wales, while in the second, Dr W. B. Spry (Garth Angharad Hospital) presented a paper on recent developments at that hospital.

At its Biannual General Meeting, the Chairman of the Division for the past two years, Dr J. Cuthill (Morgannwg Hospital), relinquished office and Dr J. M. Hughes (St Cadoc's Hospital) took over, thanking the retiring Chairman and Secretary (Dr A. Kellam) for their work for the College in Wales.

In the evening the Welsh Division Dinner was held at College House, University College, Swansea. Professor Rawnsley was formally congratulated by the Division on his election as President and received new Members and Fellows.

The Autumn Meeting was held at St Cadoc's Hospital, Caerleon, on 4 December. Dr Brian Calcraft (Royal Gwent Hospital) spoke on the 'Irritable Bowel Syndrome' and Dr Delyth Alldrick (St Cadoc's Hospital) presented a paper on 'Aspects of Liaison Psychiatry'.
The Psychotherapy and Child Psychiatry Sections contributed to the afternoon programme. Dr Ronald Westerholm spoke on the work of a Psychotherapy Unit at Cefn Coed Hospital, while Dr G. S. Thomas (St Cadoc's Hospital) reviewed the literature on dysmorphophobia and summarized the management of adolescents who had presented to the Adolescent Unit with such a picture.

The Executive Committee met quarterly throughtout the year and reported to the Welsh Office on the following: the review of ECT treatment in Wales; comments on Care in the Community; matters of concern in regard to the Mental Health (Amendment) Act proposals; breaches of confidentiality in an HAS Report; and the proposals for Services for the Mentally Handicapped in Wales.

Dr Cuthill was nominated by the Welsh Division and appointed by the Council as Regional Psychiatrist in place of Professor Rawnsley. Dr E. Kapp retired from the Editorship of the College's 'Welsh Newsletter' and Dr Gareth Jones took over.

The Welsh Postgraduate Committee (following pressure from the Executive and the Postgraduate Section in Wales) agreed to recognize a Working Party of Clinical Tutors in Psychiatry.

A. B. Rolfe

Honorary Secretary

\section{Midlands Division}

The Spring Meeting of the Midlands Division took place at the Education Centre and Main Hall at Hollymoor Hospital, Birmingham on 18 March 1983.

Professor C. P. Seager (Chairman) opened the scientific session, which was attended by 250 delegates. He introduced Professor R. Bluglass who gave a talk entitled 'The Mental 
Health Act 1983'. Professor Bluglass discussed the amendment Bill and the new Act in detail; this was followed by general discussion.

During the afternoon session, Dr T. W. Fenton (Hollymoor Hospital, Birmingham) gave the psychiatrist's viewpoint on the new Act and how it might affect the management of patients. Dr Fenton felt on the whole the new Act was not as drastic as had been originally proposed in the Mental Health (Amendment) Bill 1982. Mr Peter Mellor (Royal College of Nursing) then expressed the view from the nursing point of view and Mr R. McDonald (Sheffield Social Services) gave the opinion of the social workers, including his anxieties over the training of approved social workers.

The main points of discussion at the Business Meeting were the proposed changes in the College's Bye-Laws, the future of consultants in psychiatry and various other issues in which the College is involved at present.

At the Divisional Elections, Professor Seager, the outgoing Chairman, informed the meeting that he will be resigning from his remaining one year tenure of office as a Fellow on the Council to make room for the newly elected Chairman to take up his responsibilities as a Fellow on the Council. The following were elected: Chairman and Fellow on the Council: Dr N. Kaye (Carlton Hayes Hospital, Leics); Secretary and Honorary Member on the Council: Dr K. Raychaudhuri (Hollymoor Hospital, Birmingham).

Professor Seager (out-going Chairman) and Dr $L$. Liebling (out-going Secretary) will continue to serve on the Executive Committee for the next two years. Dr Kacmarcuk and Dr R. Hawley will be trainee members for Trent Region and West Midlands Region, respectively.

KUNAL RAYCHAUDHURI Honorary Secretary

\section{Irish Division}

The Spring Quarterly Meeting of the Irish Division was held at the Sacred Heart Home, Castlebar, on 16 April 1983.

Two speakers from St Mary's Hospital, Castlebar, were presented: Dr Deirdre Garvey detailed a survey of alcoholic admissions over a three-year period, and Dr Patricia Noone spoke on psychotherapy supervision. Both papers evoked considerable interest and discussion from a large assembly.

The Business Meeting was informed of the on-going discussions with Department of Health officials. An independent monitoring body to oversee psychiatric facilities is being adopted by the Irish Division, and other professional organizations involved in patient care will be approached in the near future with a view to enlisting their support.

Concern was expressed by various members at the manner in which Community Psychiatric Nurses operate within certain Health Boards. The Chairman informed the members that the Executive had agreed that the post of
Chief Psychiatrist, Department of Health, should be on a secondment basis for a period of three to five years. The salary should be commensurate, at least, with that of Clinical Director and return to his previous employment should be guaranteed without any loss of pension rights, etc.

The members expressed their appreciation to Drs John Connolly and Michael Gilvarry for hosting such a successful and well-attended meeting.

The Summer Quarterly Meeting took place in Purdysburn Hospital, Belfast on 25 June 1983.

The clinical programme consisted of two papers. Dr A. Montgomery's paper, 'Electro-physiological changes in minor head injury', detailed her own work and suggested that post-concussional syndrome might include three separate syndromes: an acute group; a chronic group; and a chronic, but neurotic group, with no abnormal brain-stem potentials, in contrast to the first two groups.

The second paper, by Dr D. Brennan, 'Epilepsy and its relationship to the psychiatric hospital', detailed the early and more modern accounts in the English literature of hospitalized epileptic patients. It was felt that the study of epileptics in psychiatric hospitals was neglected in the past and had led to many false assumptions. Dr Brennan detailed his own survey of epileptics in a chronic patient population at Purdysburn Hospital.

The Business Meeting was informed that our submission regarding the Post of Chief Psychiatrist, Department of Health, had been lodged with the Department. The Honorary Secretary stated that various members of the Division were concerned at developments in Community Psychiatric Nursing. The Division has been requested by a working party to submit its views on this matter. The Irish Division felt that it is incumbent upon the Department to insist that Community Psychiatric Nurses work closely with the psychiatrist as a member of the multidisciplinary team.

The Division had sought the Department's views on shared posts and part-time posts in psychiatry. The Secretary will be seeking the views of the Post-Graduate Medical and Dental Board, the IMA and the IMU on this matter in the near future.

Elections of officers and Executive took place. Dr Gordon McCallum was elected as the new Chairman; Professor T. Fahy was elected as Vice-Chairman and Fellow on Council; and Dr D. Shanley was elected as Honorary Secretary and Member on Council.

The Irish Division expressed its sincere appreciation to Professor Thomas Lynch for his invaluable work on behalf of the Division over the past four years.

The members were most grateful to Dr Gordon McCallum and to Sir Thomas Browne, Chairman of the Eastern Health and Social Services Board, for hosting the meeting.

David Shanley Honorary Secretary 